\title{
RESULTS OF ANALYSIS AND FORECASTING OF THE MAIN FINANCIAL INDICATORS OF THE HEALTH INSURANCE MARKET DEVELOPMENT IN UKRAINE
}

\author{
Liliia Hala \\ Department of Organization and Economy of Pharmacy \\ Bogomolets National Medical University \\ 13 Shevchenko blvd., Kyiv, Ukraine, 01601 \\ hala.liliia@gmail.com
}

\begin{abstract}
In recent years Ukraine against the background of systemic crisis trying to reform socially-oriented areas of society, including voluntary health insurance, which must combine market and social burdens. Under these conditions, an important scientific and practical research is forecasting financial indicators of domestic insurance companies.

Aim. Conducting analysis and forecasting of the basic indicators that characterize the financial state of development of the domestic health insurance market.

Materials and methods. Research materials were selected from the official websites of the National Commission which carry out state markets regulation of financial services and the League of Insurance Organizations of Ukraine for 2009-2018 years. We used historical, analytical and comparative, systematic, logical, hypothetical-deductive, mathematical and statistical methods.

Results. To forecast the financial indicators of the health insurance market in Ukraine (gross insurance premiums and payments; operations transferred to reinsurance, including non-residents; net insurance premiums and payments) for 2019-2020 years; the time interval was set from 2009 year. According to the results of the calculations, we obtained regression models for different financial indicators (6 models). With the help of the selected mathematical tools, the main financial indicators of the market development for 2019-2020 years were forecasted. The analysis of the data revealed that the highest value growth rate (\%) in 2020 year will be characteristic of reinsurance operations, including those transferred to non-residents $(49.06 \%)$ and the lowest - to gross insurance payments $(14,41 \%)$.

It is established that the indicator of net insurance payments since 2010 year has been steadily decreasing (from $78.19 \%$ ), and according to the forecasted data in 2019 year it may be equal to $46.77 \%$, and in 2020 year $-44.98 \%$, the trend will continue to decrease. However, this indicator since 2016 year (53.9\%) and the data forecast for 2019-2020 years are in the regulatory range (from $30.0 \%$ to $60.0 \%$ for different types of insurance activities).

Conclusions. According to the results of the research, it is established that in spite of the financial and economic crisis since 2014 year, the domestic health insurance market is characterized by positive dynamics of growth of the main financial indicators (gross insurance premiums and payments, net insurance premiums and payments). At the same time, there is a tendency to decrease the level (\%) of net insurance payments indicator from $78.19 \%$ in 2010 year to the forecast in 2020 year $-44.98 \%$.
\end{abstract}

Keywords: health insurance, insurance premiums, insurance payments, health insurance market in Ukraine.

DOI: $10.21303 / 2504-5679.2019 .001061$

\section{Introduction}

Given the increasing demands of society for the efficiency and accessibility of providing medical and pharmaceutical assistance to the population, the functioning of the health insurance market is viewed from a fundamentally new perspective. Major financial institutions aim is to develop a reliable protection of the population in case of illness, disability, appear in civil society as essential components of creating a modern infrastructure of the state. In recent years the world has seen the trend towards expanding the range of services provided by the health insurance market (HI) towards the introduction of more flexible tariff policy [1-4], because underfunding and spending on HI reduce the fiscal solvency of state and local governments - Morrill S. M. [1]. Scientists of many countries, studies aimed at finding the optimal combination of different funding mechanisms of HI, particularly for vulnerable groups of population, the elderly, to eliminate physical and socio-economic barriers to accessing services [2, 3]. For example, Kuzheliev O. M., Sokyrko O. S. proposed for use in Ukraine the model of development of insurance markets of Poland and Latvia, which will allow to increase by one third insurance premiums [4]. 
The World Health Organization and international humanitarian organizations are drawing the world's attention to expanding the practice of introducing a microinsurance model in countries undergoing health care reform or in low-income countries [5]. Thus, the experience of implementing microinsurance in the social protection system of Vietnam suggests that this form of HI is socially-adapted to the low-income conditions of most citizens. Microinsurance, as a modern form of insurance activity, is advisable as addition to ensure the principles of universality, solidarity and fairness in the system of medical and pharmaceutical assistance [6]. The United Nations and most governments around the world are promoting universal health coverage by combining a variety of funding tools, including voluntary health insurance (VHI), and microinsurance, in general to help maintain social stability in the country and require development, financial responsibility and literacy of the population in the HI questions [7].

Every year, the complementary HI program is spreading $[1,3]$. The process of introducing and reformatting insurance relations in the process of organizing and providing to population medical and pharmaceutical services is developing in the direction of widening the range of their accessibility for different citizens. This trend in the socio-economic development of different countries is, in our opinion, essential humanitarian values.

For several years, Ukraine has been developing in a systemic crisis, trying to reform the very process of state formation and practically all spheres of public life, including socially oriented spheres activity of society. With full responsibility voluntary health insurance (VHI) can be attributed to the most important areas of social activity, which must simultaneously combine market and social burden in the organization of their activities in the state. Ukrainian scientists have established the influence of the components and content of HI programs on the quality of service provision, first of all, provided that the liability of insurers is limited in certain cases [8]. The efficiency of the reform of the health care system, declared by the government of the country, depends directly on the macroeconomic conditions (level of health care costs, specific share of state participation in providing medical and pharmaceutical care, low income of the population, etc.) as a result leads to a limitation of financial capacity in the organization of assistance [9]. However, Melnyk O., Kulbachna L., Zhulim M. determined that the insurance market, as the second largest capitalization among other non-banking financial markets in Ukraine, has considerable development potential and is gradually adapting to the requirements of the European and world markets towards the introduction of socially adapted forms and methods of the population serving [10]. Therefore, every year more and more important scientific and practical importance of research aimed at analyzing and forecasting key financial indicators characterizing the activities of domestic insurance companies VHI are done. This assertion made it possible to formulate the main purpose of our research.

The aim - to study the dynamics of changes and to forecast the main indicators which characterizing the financial state of the development of the HI market in Ukraine.

\section{Materials and methods}

The objects of the study were materials that presented on the official sites of the National Commission, which implements state regulation in the sphere of financial services markets and the League of Insurance Organizations of Ukraine for 2009-2018. In the analysis we used data on indicators of gross insurance premiums and payments, operations which transferred to reinsurance, including non-residents, net insurance premiums and payments (Table 1). In addition, we calculated the level of net insurance payments.

Insurance premiums is money that was accumulated by the insurer for insurance contracts, and money means, received under reinsurance contracts that were entered into with other insurance companies on the market [8]. Another important indicator that characterizes the financial condition of insurers is insurance payments. This indicator allows to estimate the amount of money actually paid by the insurer under the insurance contracts to persons who were insured by the insurance company $[8,9]$. The level of net insurance payments is calculated as the ratio of net insurance payments to insurance premiums (\%). As mentioned in the special literature, the results of the analysis of the level of insurance payments can assess the financial stability of the insurance company $[10,11]$. This indicator also demonstrates the level of consumer confidence in insurance products 
offered in the insurance market. The optimal value of the index of insurance payments in the countries with highly developed insurance market and high standards of providing insurance services to the population ranges from $30.0 \%$ to $60.0 \%$ for different types of insurance activities [12-14].

Table 1

Interim data for carrying out analysis and forecasting of financial indicators which characterizing the state of development of the domestic market of $\mathrm{HI}$ in Ukraine

\begin{tabular}{|c|c|c|c|c|c|c|c|c|c|c|}
\hline \multirow{2}{*}{$\begin{array}{l}\text { HI indicators } \\
\text { (unit of mea- } \\
\text { surement) }\end{array}$} & \multicolumn{10}{|c|}{ VHI programs by years } \\
\hline & 2009 & 2010 & 2011 & 2012 & 2013 & 2014 & 2015 & 2016 & 2017 & 2018 \\
\hline $\begin{array}{l}\text { The number of } \\
\text { concluded con- } \\
\text { tracts (units). }\end{array}$ & 3752443 & 3028535 & 4099348 & 5616090 & 29399211 & 5861402 & 4537625 & 6106402 & 10655040 & 12086732 \\
\hline $\begin{array}{l}\text { Gross insurance } \\
\text { premiums, } \\
\text { (thousand UAH) }\end{array}$ & 1074535,3 & 1233584,1 & 1656183,0 & 1965202,3 & 2195788,0 & 2265692,3 & 2689432,7 & 3375087,3 & 4177399,0 & 5324439,7 \\
\hline $\begin{array}{l}\text { Gross insurance } \\
\text { payments, } \\
\text { (thousand UAH) }\end{array}$ & 665760,0 & 757518,2 & 889642,8 & 1062242,1 & 1179382,4 & 1289053,1 & 1415121,1 & 1581833,3 & 1968096,6 & 2441661,9 \\
\hline $\begin{array}{l}\text { On reinsurance } \\
\text { transferred, } \\
\text { including } \\
\text { non-residents, } \\
\text { (thousand UAH) }\end{array}$ & $\begin{array}{c}63878,8 \\
8115,1\end{array}$ & $\begin{array}{c}86489,4 \\
15133,4\end{array}$ & $\begin{array}{c}108743,1 \\
13743,9\end{array}$ & $\begin{array}{c}57340,6 \\
6493,2\end{array}$ & $\begin{array}{c}112656,5 \\
8059,6\end{array}$ & $\begin{array}{c}165038,8 \\
29107,0\end{array}$ & $\begin{array}{c}177121,1 \\
85129,9\end{array}$ & $\begin{array}{l}392593,3 \\
259488,1\end{array}$ & $\begin{array}{l}417474,5 \\
146448,5\end{array}$ & $\begin{array}{l}657926,5 \\
150446,0\end{array}$ \\
\hline $\begin{array}{c}\text { Net insurance } \\
\text { premiums, } \\
\text { (thousand UAH) }\end{array}$ & 1018723,8 & 1162139,1 & 1081403,2 & 1914319,3 & 20911155,7 & 2129758,4 & 2596996,5 & 3241937.5 & 3901975,6 & 4815682,8 \\
\hline $\begin{array}{c}\text { Net insurance } \\
\text { payments, } \\
\text { (thousand UAH) }\end{array}$ & 656756,3 & 754760,4 & 877677,2 & 1061959,5 & 1178063,3 & 1287943,4 & 1414333,9 & 1579757,4 & 1965578,2 & 2439807,1 \\
\hline
\end{tabular}

The next stage of our research was the analysis of specialist literature on purpose to select the necessary tools [15-17]. According to the results of a preliminary data analysis, it was decided to use a relatively easy to use least squares method (LSM) $[15,18]$. This method is used to estimate linear models. As is known, linear one-factor regression has the following form:

$$
y(t)=a_{0}+a_{1} t
$$

where $a_{0}, a_{1}-$ model coefficients (parameters).

The following matrix equation is used to calculate the coefficient estimation matrix:

$$
A=\left(X^{T} X\right)^{-1} X^{T} Y=C X^{T} Y
$$

where $X$ - planar matrix of dimension $2 \times 2$ and, when selected as independent variables of a simple function of the form $f=t$, it corresponds to the description.

$$
X=\left[\begin{array}{cc}
N & \sum_{i=1}^{N} t_{i} \\
\sum_{i=1}^{N} t_{i} & \sum_{i=1}^{N} t_{i}^{2}
\end{array}\right],
$$

where $X^{T}$ - the plan matrix is transposed, $C$ - the dispersion matrix, $Y$ - the vector column of the values of the original variable $[15,17]$.

According to the financial indicators which characterizing the dynamics of the development of the HI market in Ukraine, all the calculations were made by us at the prices valid for the 
respective period (2009-2018 years), and the necessary statistical data processing was carried out using the Microsoft Office Excel 2010 spreadsheet processor. After pre-processing, all indicators were imported into the standard statistical analysis application program Statistica 6.0 (software license V.7. English - V.6 Russia K 892818). In the processing of statistics, a value of $\mathrm{p}<0.05$ was considered statistically significant.

In the studies used historical, analytical and comparative, systemic, logical, hypotheticaldeductive, mathematical and statistical methods of scientific search and cognition.

\section{Results}

An important condition for the application of LSM is the presence of a linear model in parameters. The model can be written as a nonlinear parameter, but with the help of regression equation and parameter redefinition it must be move to a linear form $[15,17,18]$. These models are called linear internally and in their composition include, for example, polynomial $y(t)=a_{0}+a_{1} t+a_{2} t^{2}+\ldots+a_{m} t^{m}$, log-linear $\ln y=a_{0}+a_{1} \ln t$, semi-log graph $y=a_{0}+a_{1} \ln t$, exponential $y=a_{0} a_{1}^{t}$ and another models. So, before checking the adequacy of the regression models, we needed to check the significance of each regression coefficient, that is verifiable hypothesis possibility of reducing to zero each regression coefficients. For this purpose, the calculated value of Student's t test for each coefficient:

$$
t_{a_{0}}=\frac{a_{0} \sqrt{\sum_{i=1}^{N}\left(t_{i}-\bar{t}\right)^{2}}}{\sqrt{\sigma_{\varepsilon}^{2} \frac{1}{N} \sum_{i=1}^{N} t_{i}^{2}}} ; t_{a_{1}}=\frac{a_{1} \sqrt{\sum_{i=1}^{N}\left(t_{i}-\bar{t}\right)^{2}}}{\sqrt{\sigma_{\varepsilon}^{2}}}
$$

where $\sigma_{\varepsilon}^{2}=\frac{\sum_{i=1}^{N}\left(y_{i}-a_{0}-a_{1} t_{i}\right)^{2}}{N-2}-$ unbiased error variance estimate; $\bar{t}=\frac{1}{N} \sum_{i=1}^{N} t_{i}$ - estimation of the mean value of the predictor $t$.

Hypothesis $H_{0}$ was rejected when:

$$
\left|t_{a_{h}}\right|>t_{0.975}(N-2), j \in\{0 ; 1\}
$$

where $t_{0.975}(N-2)$ - a random indicator, what has Student's t-distribution with $N-2$ degrees of freedom.

Quite often in mathematical statistical packages by value $\left|t_{a_{j}}\right|$ the probability of an error of type 1 , which is marked $p$-value. In case $p$-value $<0,025$, then the hypothesis $H_{0}$ is deflect, that is, the coefficient $a_{j} \neq 0$ is meaning $[15,17]$.

The most common method in statistics choice between alternative models are available with the accuracy of selection [15]. As an indicator of accuracy using the selection coefficient of determination $R^{2}$ :

$$
R^{2}=1-\varphi^{2}
$$

where $\varphi^{2}=\frac{\sum_{i=1}^{N}\left(y_{i}-a_{0}-a_{1} t_{i}\right)^{2}}{\sum_{i=1}^{N}\left(y_{1}-\bar{y}\right)^{2}}-$ the convergence coefficient; $y_{i}-$ the experimental value of the target trait in the $i$-th experiment; $t_{i}$ - the value of the predictor in the $i$-th experiment; $\bar{y}=\frac{1}{N} \sum_{i=1}^{N} y_{i}-$ estimate of the mean value of the target trait $y ; N$ - number of experiments. 
The coefficient of determination $R^{2}$ takes a value in the range from 0 to 1 and shows that the dispersion of target features y explained by the regression equation. The higher the value $R^{2}$, whereby the greater part of the dispersion of target trait $y$ explained level of regression, and regression equation accurately describes the relationship between the respective indices. In case of the absence of a relationship between $y$ and $t$, the determination coefficient $R^{2}$ should be close to 0 . Taking into account the above, in the forecasting of indicators of the development of the domestic market of HI for 2019-2020 years, in order to select the type of regression dependence, the adequacy of the following models was checked: linear $y(t)=a_{0}+a_{1} t$, log-linear $\ln y=a_{0}+a_{1} \ln t$, semi-log graph $y=a_{0}+a_{1} \ln t$ and exponential $y=a_{0} a_{1}^{t}$ (Table 2). The analysis values of determination that we are given in tab. 2 give to suggests that the desired result is observed in the case of it log-linear $\ln y=a_{0}+a_{1} \ln t$ or exponential $y=a_{0} a_{1}^{t}$ models. In the future, we have chosen an exponential model $y=a_{0} a_{1}^{t}$ to forecast the financial indicators of the HI market in Ukraine. This choice is due to the fact that, given the same values of the coefficient of determination in reducing the exponential model to linear, only one transformation of the variable $\ln y=a_{0}+a_{1} t$ is needed $[15,19,20]$.

Table 2

Determination coefficients $R^{2}$ are calculated

\begin{tabular}{ccccc}
\hline \multirow{2}{*}{$\begin{array}{c}\text { Financial indicators of the development of the HI } \\
\text { market }\end{array}$} & \multicolumn{3}{c}{ Determination coefficients $\mathbf{R}^{2}$ for different types of the models } \\
\cline { 2 - 5 } & $\mathbf{1}^{*}$ & $\mathbf{2}^{* *}$ & $\mathbf{3}^{* * *}$ & $\mathbf{4} * * *$ \\
\hline Gross insurance premiums & 0.892 & $\mathbf{0 . 9 7 7}$ & 0.892 & $\mathbf{0 . 9 7 7}$ \\
Gross insurance payments & 0.915 & $\mathbf{0 . 9 8 4}$ & 0.915 & $\mathbf{0 . 9 8 4}$ \\
On reinsurance transferred, including non-residents & 0.734 & $\mathbf{0 . 8 4 1}$ & 0.733 & $\mathbf{0 . 8 4 1}$ \\
Net insurance premiums & 0.557 & $\mathbf{0 . 7 1 2}$ & 0.556 & $\mathbf{0 . 7 1 2}$ \\
Net insurance payments & 0.912 & $\mathbf{0 . 9 5 7}$ & 0.912 & $\mathbf{0 . 9 5 7}$ \\
\end{tabular}

Note: $1^{*}$-linear model; $2^{* *}$-log-linear model; $3^{* * *}$-semi-log graph model; $4^{* * * *}$ - exponential model. For all without exception the coefficients of determination $p<0.05$

To predict these indicators for 2019-2020 years' independent variable (predictor) $t$ values were selected time interval, which started from 2009. As the regression model, as noted previously, we proposed an exponential $\left(y=a_{0} a_{1}^{t}\right)$, so all indicators of the domestic insurance market dynamics in HI had logarithm years. According to the results of the calculations, regression models were obtained for different financial indicators (6 models). For each model, the significance of the regression coefficients and the determination coefficients were checked (Table 3 ).

Table 3

The results of calculations of the parameters of 6 exponential models

\begin{tabular}{ccccccc}
\hline HI indicators & \multicolumn{2}{c}{$\begin{array}{c}\text { Model } \\
\text { coefficients }\end{array}$} & \multicolumn{2}{c}{$\begin{array}{c}\text { The value of the Stu- } \\
\text { dent criterion }\end{array}$} & $\begin{array}{c}\text { Determination } \\
\text { coefficient }\end{array}$ \\
\cline { 2 - 6 } & \multicolumn{2}{c}{$\mathbf{a}_{\mathbf{0}}$} & $\mathbf{a}_{1}$ & $t_{a_{0}}$ & $t_{a_{1}}$ & $\mathbf{R}^{\mathbf{2}}$ \\
\hline Gross insurance premiums & -320.616 & 0.167 & -18.8808 & 19.7437 & 0.977 \\
Gross insurance payments & -256.959 & 0.135 & -22.1514 & 23.3601 & 0.984 \\
& -502.884 & 0.256 & -6.81316 & 6.97566 & 0.841 \\
On reinsurance transferred, including non-residents & -793.335 & 0.399 & -4.76499 & 4.82736 & 0.712 \\
& -337.879 & 0.175 & -13.5548 & 14.1390 & 0.957 \\
Net insurance premiums & -259.316 & 0.136 & -22.2926 & 23.4977 & 0.984
\end{tabular}

After checking the significance of the regression coefficients, we can state their significance for all 6 models (all $p$-value $<0.025$ ). All models are built on the 6 financial indicators (gross premiums and payments, the amount transferred for reinsurance, including non-residents, net premiums 
and payments) is mathematically appropriate and accurately describe the dynamics of experimental parameters that are studied. Then, using the selected mathematical tools, was forecasted the main financial indicators of the development of the HI market in Ukraine for 2019-2020 years were projected. The research results are presented in Table 4. More clearly the dynamics of the development of indicators studied during 2009-2020 years is shown in Fig. 1-5.

Table 4

Forecast of the financial indicators which characterizing the financial state of the development of the HI market for 2019-2020 years

\begin{tabular}{lccc}
\hline \multirow{2}{*}{ Financial indicators of the development of the HI market } & \multicolumn{2}{c}{ Years } \\
\cline { 3 - 4 } & & $\mathbf{2 0 1 9}$ & $\mathbf{2 0 2 0}$ \\
\hline \multirow{2}{*}{ Gross insurance premiums } & value, thou. UAH & 5773138.7 & 6819091.2 \\
& confidence interval & {$[5116880.8 ; 6513564.1]$} & {$[5938895.1 ; 7829740.1]$} \\
Gross insurance payments & value, thou. UAH & 2574189.5 & 2945022.2 \\
& confidence interval & {$[2370501.8 ; 2795379.2]$} & {$[2679704.8 ; 3236608.7]$} \\
On reinsurance transferred, & value, thou. UAH & 660017.2 & 852334.1 \\
Including non-residents & confidence interval & {$[390626.15 ; 1115190.7]$} & {$[467433.5 ; 1554174.9]$} \\
Net insurance premiums & value, thou. UAH & 290530.08 & 433058.2 \\
Net insurance payments & confidence interval & {$[88994.6 ; 948458.8]$} & {$[111703.1 ; 1678910.2]$} \\
& value, thou. UAH & 5518551.6 & 6574205.6 \\
& confidence interval & {$[4622705.6 ; 6588006]$} & {$[5367072.3 ; 8052840.9]$}
\end{tabular}

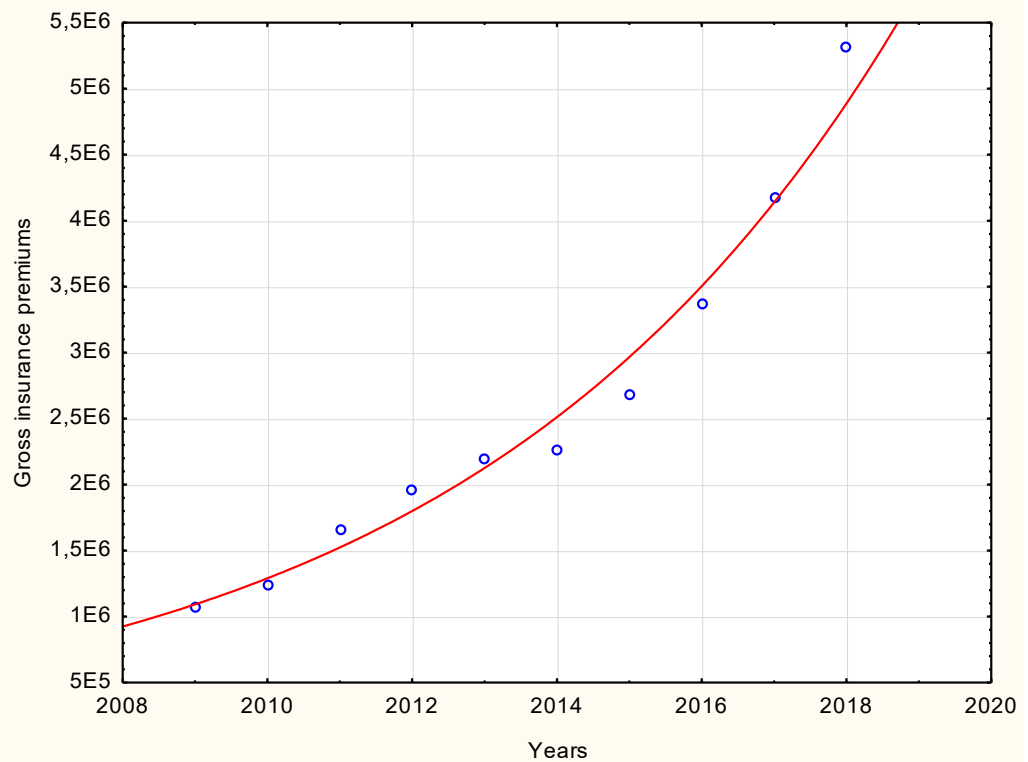

Fig. 1. Analysis of the dynamics and forecasting of gross premiums in the HI market in Ukraine (2009-2020 years)

Further, according to the tab. 4 we calculated growth rates (\%) for different financial indicators, which are being investigated in 2020 compared with the data of 2019. Thus, these indicators were equal to: gross insurance premiums $-18.12 \%$; gross insurance payments $-14.41 \%$; transferred on reinsurance operations - $29.14 \%$; transferred to reinsurance, including non-residents $49.06 \%$; net insurance premiums - $19.13 \%$; net insurance payments - $14.54 \%$. As we see, projected almost one and a half times the amount of increase amounts transferred for reinsurance to 
non-residents. This is the highest indicator of growth of financial data which characterizing the state of development of the HI market. The lowest data of forecasting data growth will be observed according to gross insurance payments $(14.41 \%)$. Subsequently, we calculated the net insurance premium rate (\%). Thus, according to the forecasted data in 2019 year, this indicator may be equal to $46.77 \%$, and in 2020 year $-44.98 \%$. For comparison, according to 2018 year, this indicator was equal to $50.37 \%$. That is, it can be argued that the level of net insurance payments made by insurers for HI operations during 2018-2020 years may have a tendency to decrease.

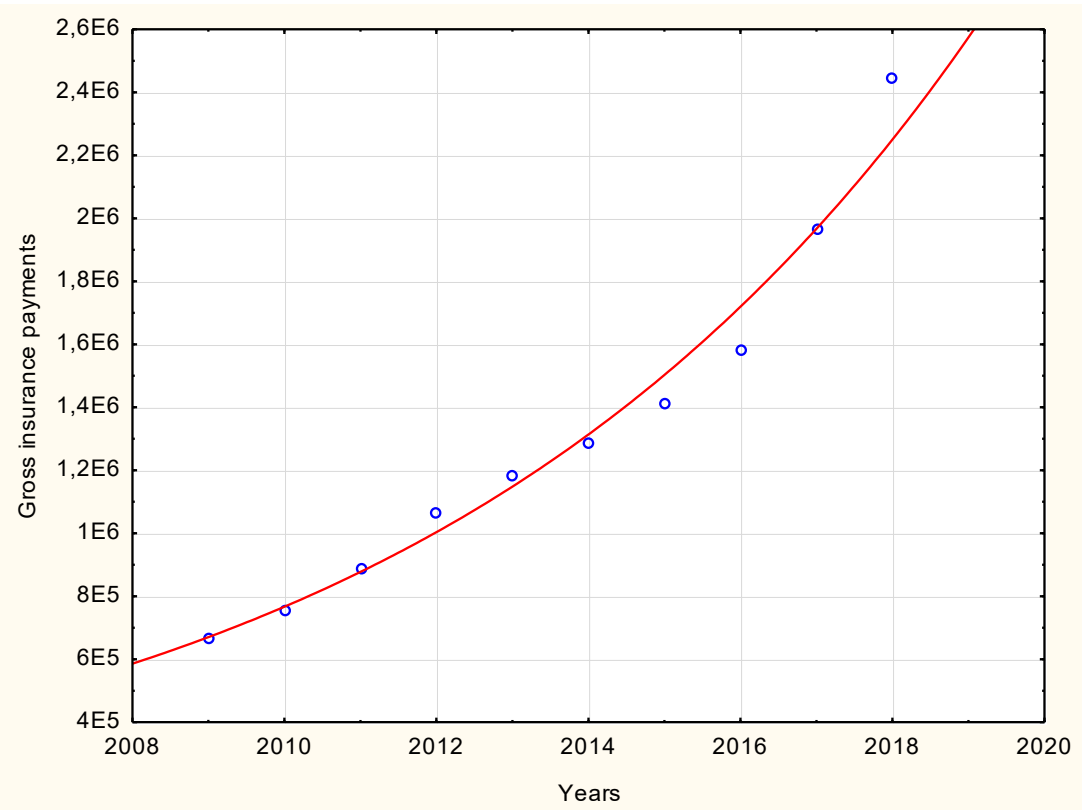

Fig. 2. Research of dynamics and results of forecasting of indicators of gross insurance payments of domestic insurers on the market of the HI in Ukraine (2009-2020 years)

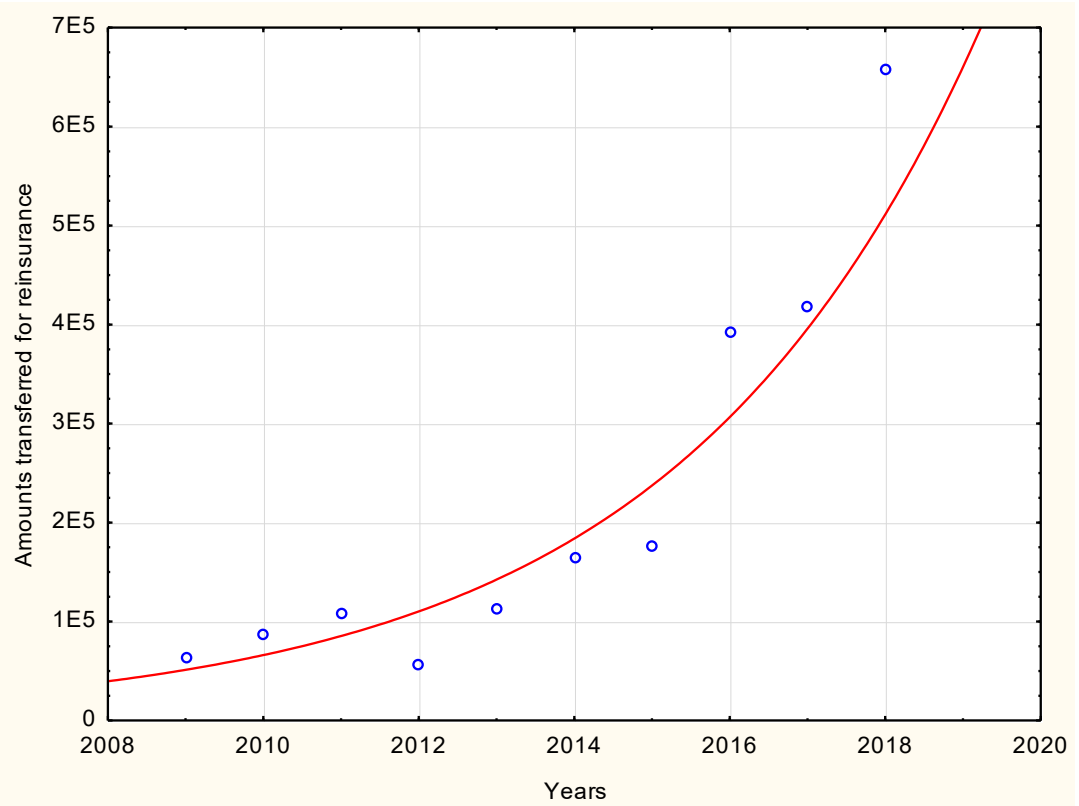

Fig. 3. Investigation of the dynamics of changes in the amounts transferred through reinsurance operations (2009-2018 years) and the results of their forecasting (2019-2020 years) in the Ukrainian HI market 


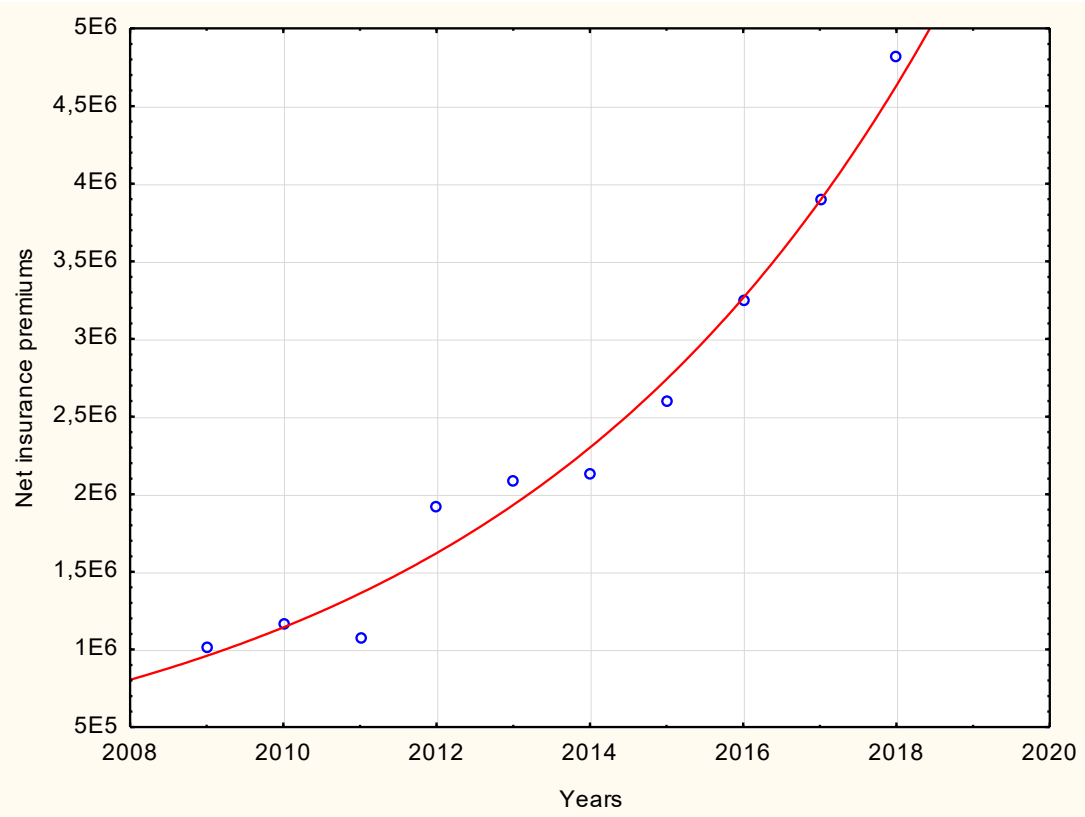

Fig. 4. Dynamics of net insurance premiums (2009-2018 years) performed by domestic insurers in the $\mathrm{HI}$ market in Ukraine and the results of forecasting these financial indicators for 2019-2020 years

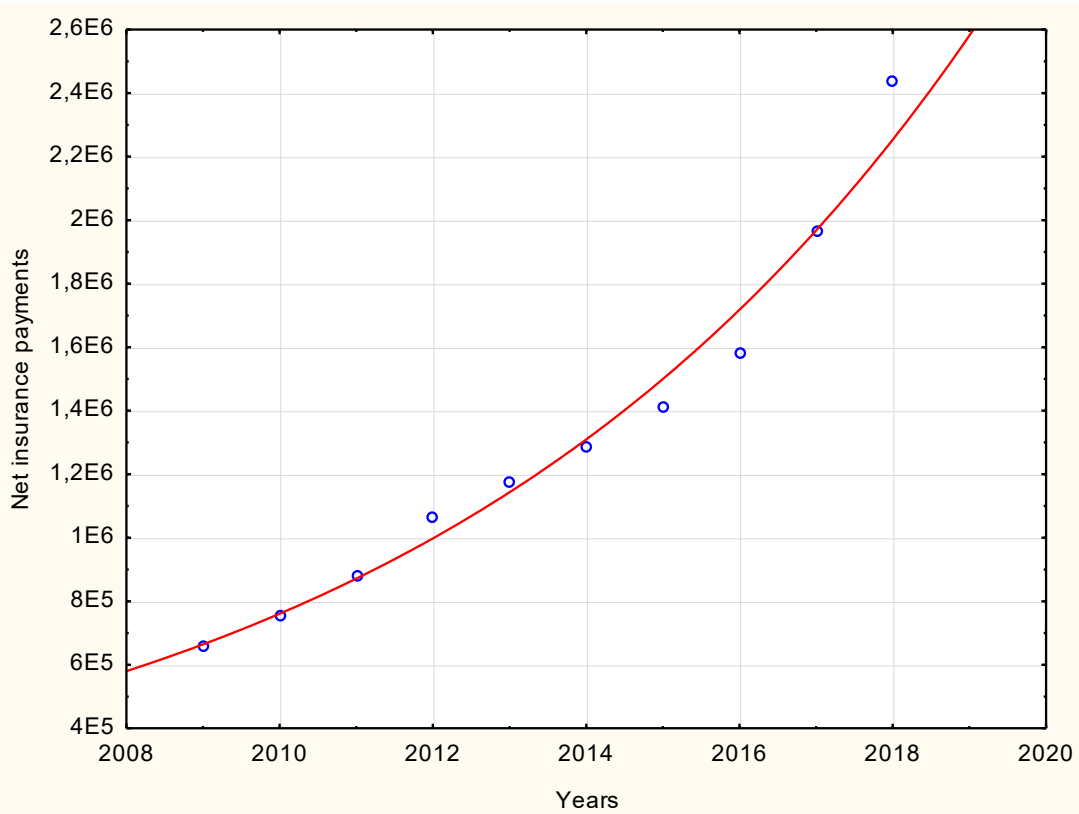

Fig. 5. Analysis of the dynamics of net insurance payments (2009-2018 years) performed by domestic insurers in the $\mathrm{HI}$ market in Ukraine and their forecast for 2019-2020 years

As we can see from the data of Fig. 6. since 2010 year in Ukraine in the HI market there has been a systematic decrease of this indicator from $78.19 \%$ in 2010 year to the forecast in 2020 year of $44.68 \%$. Taking into account the fact that the optimum value of this indicator ranges from $30.0 \%$ to $60.0 \%$ for different types of insurance activity, it can be concluded that the level (\%) of net insurance payments in the HI market in Ukraine since 2016 year and those that are projected for 2019-2020 years are within the regulatory range of relevant values. 


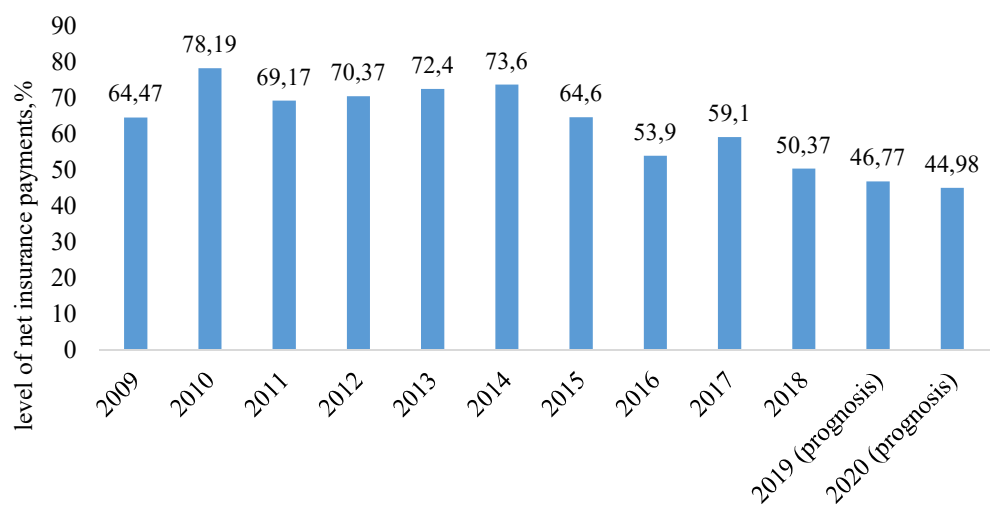

Fig. 6. Analysis of the dynamics of net insurance payments (2010-2018 years) and their forecast for 2019-2020 years according to the HI programs in Ukraine

\section{Discussion}

Analyzing the data of the specialized literature, which show the range of questions we have discussed, we can state the following. The research of the main financial indicators which characterizing the state of development of the HI market was conducted in the vast majority of economic and regulatory changes that took place in the financial market of Ukraine. The HI market segment was seen as an important component of the financial market of the country where the interests of business and society intersect. The analysis of problems and prospects of development of the mentioned segment of the insurance market, which studied from a certain point of view, leads to a significant restriction of the social burden imposed by the modern society on insurers. Currently, in most countries, the $\mathrm{HI}$ is regarded as an important form of insurance activity that forms the objective prerequisites for ensuring stability in the country. One important restriction study that we conducted, is the lack of communication of the results obtained by different administrative-territorial units of the country. Considering the significant difference between the socio-economic development of individual regions of the country, as well as the incomes of the population under the parameter "city-rural area", there is a fair question regarding the possibilities of using these indicators in forecasting the development of certain segments of the HI market. Effective use of the get results in the practical activities of insurers also requires the availability of appropriate mathematical and statistical software packages and specialists who can interpret them in a qualified manner. Nevertheless, the obtained results make it possible to outline the scientifically grounded directions of further development of the HI market at the macroeconomic level, taking into account the features of the formation of macroeconomic indicators that directly affect the welfare of the population. This statement determines the main direction of perspective research, theoretical and applied value of which will be the development of a set of measures, the effective implementation of which will contribute to the formation of socially adapted forms and methods of providing services with HI to the population regardless of material status in society. Another perspective area of our research will be the analysis and forecasting of the main indicators which characterizing insurance activity in Ukraine under separate insurance programs.

On the whole, it should be noted that despite the financial and economic crisis that began in the country since 2014 year, the HI market has shown a capacity for gradual development. An important condition for introducing insurance relations into the national health care system should be the understanding by the existing authorities of the need for systematic changes in the financing and distribution of resources in the process of providing medical and pharmaceutical assistance to the population.

Effective from an economic and social point of view the combination of mandatory and voluntary forms of $\mathrm{HI}$ in the state objective conditions to improve accessibility provision of public health and pharmaceutical services in final form is considered as a strategic direction of Ukrainian society. 


\section{Conclusions}

According to the results of our research, we have found that despite the financial and economic crisis, which has been observed in the country since 2014 year, the domestic market of HI is characterized by a positive dynamics of growth of the main financial indicators (gross insurance premiums and payments, net insurance premiums and payments).

With the help of the exponential model $\left(y=a_{0} a_{1}^{t}\right)$ the main financial indicators characterizing the state of development of the domestic market of HI in 2019-2020 years were forecasted. It is proved that the highest growth rate of data in 2020 year will be observed in reinsurance operations, including those transferred to non-residents (49.06\%), and the lowest - to gross insurance payments $(14.41 \%)$.

According to the analysis of the dynamics of changes in the level of indicator (\%) of net insurance payments, it is established that in 2019 year this indicator can be equal to $46.77 \%$, and in 2020 year $-44.98 \%$. For comparison, according to 2018 year, this indicator was $50.37 \%$.

In general, the HI market in Ukraine has a tendency to decrease the level (\%) of net insurance payments from $78.19 \%$ in 2010 year to the forecast in 2020 year of $44.68 \%$.

It is proved that since 2016 year the value (\%) of net insurance payments under the HI programs in Ukraine was in the normative range (30.0-60.0\%) of values.

\section{Conflict of interests}

No conflict of interest.

\section{References}

[1] Morrill, M. S. (2014). Active and retired public employees' health insurance: Potential data sources. Journal of Health Economics, 38, 147-152. doi: http://doi.org/10.1016/j.jhealeco.2014.06.011

[2] Mills, A., Ataguba, J. E., Akazili, J., Borghi, J., Garshong, B., Makawia, S. et. al. (2012). Equity in financing and use of health care in Ghana, South Africa, and Tanzania: implications for paths to universal coverage. The Lancet, 380 (9837), $126-133$. doi: http://doi.org/10.1016/s0140-6736(12)60357-2

[3] Shoven, J. B., Slavov, S. N. (2014). The role of retiree health insurance in the early retirement of public sector employees. Journal of Health Economics, 38, 99-108. doi: http://doi.org/10.1016/j.jhealeco.2014.03.013

[4] Kuzheliev, O. M., Sokyrko, O. S. (2015). Insurance services market development: international experience and Ukrainian realia. Actual problems of economics, 9, 365-371.

[5] Habib, S. S., Perveen, S., Khuwaja, H. M. A. (2016). The role of micro health insurance in providing financial risk protection in developing countries- a systematic review. BMC Public Health, 16 (1). doi: http://doi.org/10.1186/s12889-016-2937-9

[6] The role of microinsurance in social protection: A country study of Vietnam. (2015). Available at: https://microinsurancenetwork.org/sites/default/files/MICRO_Network-Vietnam\%20Paper\%20A4\%20(3)final_0.pdf

[7] Dror, D. M. (2018). Financing micro health insurance: Theory, Methods and Evidence. Emerging Markets, 18 (3), $192-195$.

[8] Nechyporuk, L. V. (2016). Teoriia i praktyka medychnoho strakhuvannia v Ukraini. Hlobalni ta natsionalni problemy ekonomiky, 6, 751-755.

[9] Romaniuk, P., Semigina, T. (2018). Ukrainian health care system and its chances for successful transition from Soviet legacies. Globalization and Health, 14 (1). doi: http://doi.org/10.1186/s12992-018-0439-5

[10] Melnyk, O., Kulbachna, L., Zhulim, M. (2018). Analysis of the current state of insurance market in Ukraine. Modern Economics, 7. Available at: https://modecon.mnau.edu.ua/issue/7-2018/ENG/melnyk.pdf

[11] Newsom, M., Fernandez, B. (2011). Private Health Insurance Premiums and Rate Reviews. Washington: Congressional Research Service. Available at: http://digitalcommons.ilr.cornell.edu/key_workplace/788

[12] Hartwig, R. et. al. (2010). Insurance Handbook. A guide to insurance: what it does and how it works. New York, 198.

[13] Zhuravka, O. S., Vasylchuk, A. Yu. (2017). Analiz suchasnoho stanu strakhovoho rynku Ukrainy. Efektyvna ekonomika, 3. Available at: http://www.economy.nayka.com.ua/?op=1\&z=5493

[14] Hudakova, M., Adamko, J. (2017). Technical reserves in insurance and Slovak insurance market. Economic Annals-XXI, 162 (11-12), 98-103. doi: http://doi.org/10.21003/ea.v162-20

[15] Monetary and financial statistics manual and compilation guide (2017). Washington: International Monetary Fund, 454. doi: http://doi.org/10.5089/9781513579191.069

[16] David, M. (2015). Auto Insurance Premium Calculation Using Generalized Linear Models. Procedia Economics and Finance, 20, 147-156. doi: http://doi.org/10.1016/s2212-5671(15)00059-3 
[17] Kuzmina, E. M., Pecheritsa, J. S., Grischuk, L. V. (2016). Prediction methods of enterprise financial indicators. Young Scientist, 1 (28 (1)), 89-92.

[18] Xu, Y., Patnayakuni, R., Wang, H. (2013). Logarithmic least squares method to priority for group decision making with incomplete fuzzy preference relations. Applied Mathematical Modelling, 37 (4), 2139-2152. doi: http://doi.org/10.1016/ j.apm.2012.05.010

[19] Zakharova, A. P., Vinichuk, O. Y., Maksimova, D. A. (2016). Analysis and Forecasting of Sales Volumes of the Regional Insurance Company: The Russian Experience. Journal of Internet Banking and Commerce, 21 (3). Available at: http://www. icommercecentral.com/open-access/analysis-and-forecasting-of-sales-volumes-of-the-regional-insurance-company-the-russian-experience.pdf

[20] Tkachenko, I. S., Proskurovych, O. V. (2017). Ekonomiko-matematychne modeliuvannia finansovoho rezultatu pidpryiemstva. Ekonomika: realii chasu, 3, 84-94.

Received date 14.10.2019

Accepted date 19.11.2019

Published date 30.11.2019
(C) The Author(s) 2019

This is an open access article under the CC BY license (http://creativecommons.org/licenses/by/4.0). 